\title{
PENGARUH LAYANAN INFORMASI MENGGUNAKAN MEDIA FILM TERHADAP KEPERCAYAAN DIRI SISWA KELAS XI SMA NEGERI 1 BINJAI TAHUN AJARAN 2016/2017
}

\author{
Flora Sitohang, Tumiyem, Juwita Erdaini \\ STKIP Budidaya Binjai
}

\begin{abstract}
Abstrak
Tujuan penelitian ini ada untuk mengetahui pengaruh layanan informasi menggunakan media film terhaap kepercayaan diri siswa kelas XI SMA Negeri 1 Binjai Tahun Pelajaran 2016/2017. Manfaat dari penelitian ini sebagai informasi ilmiah yang dapat digunakan sebagai upaya untuk menambah khasanah dan pengembangan wacana pendidikan yang berkenaan dengan ilmu pengetahuan di bidang bimbingan dan konseling pada umumnya, dan menambah kajian bagi psikologi tentang pengaruh laynan informasi menggunakan media film terhadap kepercayaan diri.Jenis penelitian ini adalah kuantitatif.Populasi dalam penelitian ini adalah seluruh siswa kela XI SMA N 1 Binjai Tahun Pelajaran 2016/2017.Sampel dalam penelitian ini adalah keseluruhan siswa (populasi) yang berjumlah 80 orang siswa. Pengumpulan data dalam penelitian ini menggunakan angket layanan informasi menggunkan media film dan angket kepercayan diri siswa yang masing-masing berjumlah 6 item soal yang sebelumnya telah diuji coba sehingga bias digunakan dalam penelitian. Metode analisis data dalam penelitian ini adalah menggunakan uji asosiatif (pengeruh) dengan rumus korelasi product moment untuk mengetahui signifikaannya dilanjutkan menggunakan uji t. Dari hasil penelitian diperoleh data Variabel X dengan Mean= 16.80, $\mathrm{SD}=4.300$ dengan $\mathrm{N}=80$ orang siswa dan Variabel $\mathrm{Y}$ dengan Mean=17.00, $\mathrm{SD}=4.314$ dengan $\mathrm{N}=80$ orang siswa. Dengan hasil penelitian perhitungan nalisis, hasil $\mathrm{t}_{\text {hitung }}=17,27$ dengan taraf signifikan nyata $\alpha=0,05$ dan dk yaitu $\mathrm{n}=80-2=78$. Kemudian dapat dikatakan terdapat pengaruh yang signifikan antara kedua variabel jika $t_{\text {hitung }}>t$ tabel , dengan ketentuan nilai $t_{\text {tabel }}=$ 1,98 , jadi dapat dilihat bahwa 17,27>1,98 sehingga dapat disimpulkan bahwa terdapat pengaruh layanan informasi menggunakan media film terhadap kepercayaan diri siswa kelas XI SMA Negeri 1 Binjai Tahun Pelajaran 2016/2017 dengan demikian hipotesis dinyatakan diterima. Diharapkan untuk peneliti yang akan selanjutnya hendaknya dapat melakukan penelitian mengenai masalah percaya diri dengan kondisi subjek yang berbeda, namun menggunakan layanan dan teknik yang sama tetapi dengan masalah yang berbeda dalam melaksanakan penelitian berikutnya.

kata kunci : layanan informasi, kepercayaan diri
\end{abstract}

\section{PENDAHULUAN}

Pendidikan pada hakekatnya adalah usaha sadar untuk mengembangkan kepribadian dan kemampuan siswa di dalam, diluar sekolah, keluarga dan masyarakat. Hal ini sesuai dengan Undang-Undang No. 20 Tahun 2003 tentang sistem pendidikan Nasional bahwa: "Pendidikan adalah usaha sadar terencana untuk mewujudkan suasana belajar dan proses pembelajarn agar peserta didik secara aktif mengembangkan potensi dirinya untuk memiliki kekuatan spritual keagamaan, pengendalian diri, kepribadian, kecerdasan, akhlak mulia serta keterampilan yang diperlukan dirinya, masyarakat, bangsa dan negara”.

Bimbingan dan konseling bagian integral dari pendidikan, Oleh karena itu Bimbingan dan Konseling di sekolah harus di laksanakan.Penyelenggraan bimbingan dan konseling 
berperan untuk membantu siswa menemukan pribadinya dan kelemahan dirinya serta menerima dirinya secara positif dan dinamis sebagai modal pengembangan diri lebih lanjut.Bimbingan dan Konseling juga membantu dalam rangka mengenal lingkungan sosialnya, seperti lingkungan rumah, lingkungan sekolah dan lingkungan masyarakat serta lingkungan yang lebih luas dan diharapkan dapat menunjang sebagai manfaat bagi siswa dalam pengembangan diri secara mantap dan berkelanjutan.

Keberhasilan siswa dalam belajar dan kehidupannya tidak hanya ditentukan oleh kecerdasan otaknya saja.Kematangan emosi, keterampilan sosial, kepercayaan diri, dan kesantunan berprilaku merupakan faktor yang sangat menentukan dalam keberhasilan siswa.

Dengan demikian pembinaan terhadap seseorang tentunya tidak hanya ditekankan pada pengembangan kemampuan berpikir saja, tetapi kecerdasan emosi,percaya diri, keterampilan mpilan sosial dan kesantunan prilaku harus mendapatkan porsi yang tepat. Salah satu masalah atau hambatan yang sering dihadapi siswa dalam belajar adalah kurangnya kepercayaan diri.Rasa percaya diri merupakan suatu kekuatan atau dorongan yang ada dalam diri individu untuk melakukan suatu hal yang berpengaruh bagi kemajuan dan dalam memperbaiki diri.Percaya diri adalah suatu aspek kepribadian yang ada dalam kehidupan manusia dan sangat berpengaruh penting dalam kehidupan yang mereka lakukan. Santrock (2003)"percaya diri adalah dimensi evaluatif yang menyeluruh dari diriatau gambaran diri.". Menurut Lauster orang yang memiliki percaya diri yang positif adalah: a). Keyakinan akan kemampuan diri b). Optimis c).Obyektif d).Bertanggung jawab e).Rasional dan realistis.

Rasa kepercayaan diri hendaknya selalu tertanam pada individu walaupun sedang diharapkan dengan berbagai macam masalah.Percaya diri sangat menunjang keberhasilan belajar dan kehidupannya, dengan demikian para siswa harus bisa membangun rasa percaya diri. Berbagai masalah kurangnya kepercayaan siswa antara: 1. Siswa kurang percaya akan kemampuan yang dimilikinya 2 . Siswa merasa pesimis ketika menghadapi suaru persoalan 3 . Siswa berpandangan subyektif 4 . Siswa masih ada yang tidak mengerjakan tugas secara mandiri 5. Siswa berpikiran negatif dengan keadaan yang dimilikinya.Perilaku yang ditunjukkan oleh peserta didik di atas mgindikasikan bahwa ada permasalahan yang dialami oleh peserta didik terkait aspek kepercayaan diri.

Kondisi tersebut jika tidak mendapat perhatian yang serius akan mengakibatkan peserta didik terjebak dalam suatu permasalahan yang lebih komplek, sehingga berakibat buruk terhadap hasil belajar dan juga kesuksesan dimasa depan. Salah satu faktor yang diduga menjadi penyebab kurang percaya diri adalah penggunaan strategi dan kurangnya informasi bagi siswa tentang manfaat percaya diri.Rasa percaya diri yang rendah perlu diberikan layanan 
tentang percaya diri dengan harapan, setelah diberikan layanan informasi bisa meningkatkan rasa percaya diri siswa.

Zainal (2012) menjelaskan bahwa,'Layanan informasi yaitu layanan bimbingan dan konseling yang memungkinkan peserta didik menerima dan memahami berbagai informasi yang dapat dipergunakan sebagai bahan pertimbangan keputusan untuk kepentingan peserta didik.". Melalui layanan informasi siswa juga akan menambah wawasan dan pengetahuan yang berguna memenuhi kekurangan yang siswa miliki. Seperti halnya yang dijelaskan oleh

Prayitno(2004) bahwa: Layanan informasi merupakan suatu usaha untuk memenuhi kekurangan individu akan informasi yang mereka perlukan. Dalam layanan ini, kepada peserta layanan disampaikan berbagai informasi dan diolah dan digunakan individu untuk kepentingan hidup dan perkembangannya.Layanan informasi diselenggarakan oleh konselor dan diikuti oleh seseorang atau lebih peserta.

Sedangkan menurut Tohirin(2009)"Layanan informasi bermakna usaha-usaha membekali siswa dengan pengetahuan serta pemahaman tentang lingkungan hidupnya dan tentang proses perkembangan anak muda”. Diperlukan informasi bagi siswa semakin penting mengingat sebagai acuan bersikap dan bertingkah laku sehari-hari, sebagai pertimbangan bagi arahan pengembangan diri, dan sebagai dasar pengambilan keputusan.Dengan demikian, pemberian layanan informasi dengan materi yang sangat dibutuhkan oleh peserta didik akan sangat mambantu peserta didik memiliki rujukan dan referensi yang jelas untuk meningkatkan rasa percaya diri, baik dalam bersosialisasi dan juga dalam proses belajar.

Layanan informasi merupakan layanan yang bertujuan memberikan pemahaman tentang suatu hal kepada peserta didik. Tujuan utama dari layanan informasi adalah diperolehnya pemahaman baru dari peserta didik akan berbagai hal, seperti akademik, pribadi, sosial, dan karir. Pada dasarnya berbagai metode dalam pelaksanaan layanan informasi dapat dilakukan inovasi dengan memanfaatkan media. Tujuannya agar motivasi siswa mengikuti layanan informasi lebih tinggi, dan daya pemahaman terhadap materi layanan menjadi lebih baik.Penyampaian layanan informasi untuk memudahkan siswa memahami materi perlu ditempuh strategi layanan yang baik dan yang menarik sehingga siswa aktif mengikuti kegiatan layanan.Film bisa digunakan sebagai media dalam layanan informasi yang dapat memudahkan siswa untuk menerima isi dari layanan yang disampaikan guru pembimbing. Materi yang diberikan harus disesuaikan de gan kebutuhan siswa yaitu: membangun keyakinan diri, sifat optimis, mampu menilai secara obyektif, tanggung jawab, dan mampu berfikir rasional maupun realistis. 
Dalam observasi awal yang dilakukan penulis sebelumnya di SMA Negeri 1 Binjai di dalam proses pembelajaran tidak selalu sesuai seperti yang diharapkan. Masih terdapat siswa yang kurang memiliki kepercayaan diri.Kurang percaya diri siswa dapat terlihat ketika belajar di kelas. Maka perlu dilakukan eksperimen berupa pemberian layanan informasi menggunakan media film untuk meningkatkan kepercayaan diri peserta didik. Tujuan yang diharapkan adalah untuk mengetahui pengaruh layanan informasi menggunakan media film terhadap kepercayaan diri siswa.

Berdasarkan latar belakang diatas, maka penulis tertarik untuk meneliti tentang Pengaruh Layanan Informasi Menggunakan Media Film Terhadap Kepercayaan Diri Siswa Kelas XI SMA Negeri 1 Binjai Tahun Pelajaran 2016/2017.

\section{METODE PENELITIAN}

Lokasi penelitian ini akan dilaksanakan di SMA Negeri 1 Binjai yang berlokasi di Jalan Yos Sudarso Suka Makmur. Pemilihan lokasi ini dikarenakan peneliti mendapat kemudahan dalam memasuki sekolah tersebut,sehingga dapat mempermudah peneliti dalam memperoleh data. Penelitian ini dilaksanakan pada semester ganjil Tahun Pelajaran 2016/2017. Menurut Arikunto, populasi adalah: keseluruhan subjek penelitian. Jika seseorang ingin meneliti semua elemen yang ada dalam wilayah, maka penelitiannya merupakan penelitian populasi atau studi populasi atau sensus.Populasi dalam penelitian ini adalah siswa kelas XI SMA Negeri 1 Binjai terdiri dari 2 kelas dengan jumlah keseluruhan 80 orang dengan perincian sebagai berikut.

Tabel Keadaan Siswa Kelas XI SMA Negeri 1 Binjai Tahun Pelajaran 2016/2017

\begin{tabular}{|c|c|}
\hline JENIS KELAS & JUMLAH \\
\hline XI-1 & 40 Siswa \\
\hline XI-2 & 40 Siswa \\
\hline Jumlah & 80 Siswa \\
\hline
\end{tabular}

Sampel adalah bagian dari populasi yang diambil untuk dijadikan penelitian. Dalam Arikunto dikatakan: "sampel adalah sebagian atau wakil populasi yang diteliti”. Kemudian Arikunto mengatakan : “Apabila jumlah subjeknya kurang dari 100 maka lebih baik diambil semua sehingga penelitiannya merupakan penelitian populasi. Selanjutnya jika subjeknya besar dapat diambil antara 10\%-15\% atau 20\%- 
$25 \%$ atau lebih. Jadi karena dalam penelitian ini jumlah populasi hanya 80 orang, maka pengambilan sampel diambil secara keseluruhan yaitu yang berjumlah 80 orang.

Metode penelitian ini menggunakan metode eksperimen. Dengan menggunakan satu kelas yaitu kelas XI merupakan kelas kontrol dengan menggunakan media film dan satu kelas lagi merupakan kelas kontrol dengan menggunakan media informasi.

Menurut Arikunto, "Instrument penelitian adalah alat atau fasilitas yang digunakan oleh peneliti dalam mengumpulkan data agar pekerjaannya lebih mudah dan hasilnya lebih baik, dalam arti lebih cermat, lengkap, dan sistematis sehinnga lebih mudah diolah".

Dalam penelitian ini penulis akan menggunakan angket."Angket adalah sejumlah pertanyaan yang digunakan untuk memperoleh informasi dari responden dalam arti laporan tentang pribadinya, atau hal-hal yang ia ketahui”.

Alat pengumpulan data ini digunakan karena dapat menghemat waktu dan dapat menghimpun data atau informasi yang dibutuhkan dengan waktu relatif singkat. Setiap responden akan menerima pertanyaan dan kemungkinan jawaban yang sama, hal ini akan memudahkan penulis untuk mengelola dan menganalisis data yang diperoleh.

1. Proses Pembuatan Instrumen

Langkah- langkah yang ditempuh dalam pengadaan instrumen penelitian melalui beberapa tahap. Menurut Arikunto prosedur yang ditempuh adalah : "Perencanaan butir soal, penulisan butir soal, uji coba, penganalisaan hasil, dan pengadaan revisi terhadap item-item yang dirasa kurang baik". Untuk item yang bersifat mendukung digunakan pernyataan

Sangat Setuju (SS)

Skor 4

Setuju $(\mathrm{S})$

Skor 3

Tidak Setuju(TS)

Skor2

Sangat Tidak Setuju (STS) Skor1

Untuk mengukur kevaliditan item tes ini dengan menggunakan rumus product moment pada program SPSS version 17,0 For Windows atau dengan rumus manual sebagai berikut: 


$$
\mathrm{r}_{\mathrm{xy}}=\frac{N\left(\sum X Y-\left(\sum X\right)\left(\sum Y\right)\right.}{\left.\sqrt{\left\{N \sum X^{2}\right.}-\left(\sum X\right)^{2}\right\}\left\{N . Y^{2}-\left(\sum Y\right)^{2}\right\}}
$$

Reliabilitas dari tes ini yaitu sejauh mana hal ini memberikan hasil yang konsisten bila diberikan kepada orang yang berbeda pada kesempatan yang berbeda.Karena itu jika nilai siswa konsisten, tes ini dapat diandalkan. Untuk mengetahui apakah tes ini dapat dipercaya, penulis menggunakan bantuan program SPSS version 17,0 For Windows atau dengan rumus KR-21 sebagai berikut :

$\mathrm{KR} 21 \frac{K}{K-1}\left(1 \frac{M(K-M)}{K \cdot S^{2}}\right.$

Dimana: $\mathrm{R}=$ keandalan tes

$\mathrm{K}=$ Jumlah pertanyaan

$\mathrm{M}=$ Mean dari nilai tes

$\mathrm{S}=$ Standart deviasi

Menganalisis data merupakan salah satu cara yang digunakan untuk mengolah data penelitian guna memperoleh suatu kesimpulan. Oleh karena itu setelah data terkumpul harus segera dilakukan analisis karena apabila data tersebut tidak dianalisis data tersebut tidak dapat dugunakan untuk menjawab permasalahan yang sudah dirumuskan. Dalam penelitian ini analisis data yang digunakan adalah:

1. Uji Normalitas

Uji normalitas data yang dilakukan adalah mengetahui apakah sampel yang digunakan berdistribusi normal atau tidak. Untuk menguji normalitas data digunakan rumus Lilifors, dengan menggunakan program SPSS version 17,0 For Windows.Dengan kriteria nilai Probabilitas >0,05.

2. Uji Homogenitas

Uji homogenitas data yang digunakan untuk melihat apakah ada kedua kelompok sampel atau populasi mempunyai varians yang homegen atau tidak. Untuk ini dilakukan uji $\mathrm{F}$ yaitu dengan menggunakan program SPSS version 17,0 For Windows atau dengan rumus sebagai berikut : $\mathrm{F}=\frac{V_{b}}{V_{k}}$, dimana: 


$$
\begin{aligned}
& V_{b}=\text { varians terbesar } \\
& V_{k}=\text { varians terkecil }
\end{aligned}
$$

Dengan kriteria Jika $\mathrm{p}>0.05$ kedua sampel mempunyai varians yang sama.

\section{Uji Assosiatif(Pengaruh)}

Untuk mengetahui pengaruh layanan informasi bidang bimbingan belajar terhadap prestasi belajar siswa menggunakan rumus korelasiproduct moment dengan bantuan program SPSS version 17,0 For Windows. Dengan ketentuan $\mathrm{p}<0,05$.

4. Uji hipotesis

Untuk melihat signifikan atau tidaknya digunakan uji t-tabel, dengan rumus sebagai berikut :

$t=\frac{r \sqrt{N-2}}{\sqrt{1-r^{2}}}$

Keterangan:

$$
\begin{aligned}
& \mathrm{t}=\text { Signifikan korelasi } \\
& \mathrm{r}=\text { Koefisien korelasi } \\
& \mathrm{n}=\text { jumlah sampel }
\end{aligned}
$$

Dengan ketentuan $t_{\text {hitung }}>t_{\text {tabel }}$ maka Ha dinyatakan diterima.

\section{HASIL PENELITIAN}

Berdasarkan pada penelitian yang dilakukan terhadap siswa kelas XI SMA Negeri 1 Binjai Tahun Pelajaran 2016/2017 diperoleh Hasil dari penyebaran angket tentang pelaksanaan layanan informasi menggunakan media film terhadap kepercayaan diri siswa Hasil penelitian dimaksudkan untuk mengetahui bagaimana kondisi dari pelaksanaan pembelajaran disekolah sesuai dengan kepercayaan diri siswa, dan peneliti menelaahnya berdasarkan butir item pernyataan untuk mengetahui frekuensi masing-masing. Peneliti mengungkap layanan informasi menggunakan media film yang terdiri dari 6 item pernyataan dan kepercayaan terdiri dari 6 item pernyataan yang sudah diuji terlebih dahulu validitas dan reliabilitasnya.. Skala ini diberikan kepada 12 orang siswa yang menjadi subjek dalam penelitian ini. 
Kemudian dari sebaran data angket setelah dilakukan uji reliabilitas dan validitasnya diperoleh data Variabel $\mathrm{X}$ dengan Mean $=16.80, \mathrm{SD}=4.300$ dengan $\mathrm{N}=80$ orang siswa dan Variabel $\mathrm{Y}$ dengan Mean=17.00, $\mathrm{SD}=4.314$ dengan $\mathrm{N}=80$ orang siswa.

Berdasarkan hasil validitas perhitungan koefisien korelasi menggunakan program SPSS version 17,0 For Windows dengan kriteria pemilihan item berdasarkan koefisien korelasi sebesar 0.3 dengan signifikan $\alpha=5 \%$ butir angket nomor 1 sampai dengan 6 variabel $\mathrm{x}$ (layanan informasi menggunakan media film) dan y (kepercayaan diri) dengan harga kritis 0,3 semua butir soal dinyatakan valid. Penjelasannya dapat dilihat pada tabel berikut ini :

\section{Nilai Validitas}

\section{Variabel X dan Y}

\begin{tabular}{|c|c|c|c|}
\hline $\begin{array}{c}\text { Variabel X } \\
\text { (Layanan Informasi Menggunakan Media } \\
\text { Film) }\end{array}$ & \multicolumn{2}{c|}{$\begin{array}{c}\text { Variabel Y } \\
\text { Kepercayaan Diri ) }\end{array}$} \\
\hline No. Item & $\mathrm{r}_{\text {hitung }}$ & No. Item & $\mathrm{r}_{\text {hitung }}$ \\
\hline 1 & 0.892 & 1 & 0.659 \\
\hline 2 & 0.740 & 2 & 0.830 \\
\hline 3 & 0.699 & 3 & 0.777 \\
\hline 4 & 0.874 & 4 & 0.869 \\
\hline 5 & 0.894 & 5 & 0.889 \\
\hline 6 & 0.892 & 6 & 0.880 \\
\hline
\end{tabular}

Berdasarkan hasil perhitungan angket dengan menggunakan program SPSS version 17,0 For Windows dengan tingkat kepercayaan 95\% yang mempunyai harga kritis 0,3. Selanjutnya dapat disimpulkan bahwa angket layanan informasi menggunakan media film dan kepercayaan diri siswa memenuhi kriteria reliabilitas. Hal ini terbukti dengan hasil perhitungan menggunakan program SPSS version 17,0 For Windows sebagai berikut :

\section{Nilai Reliabilitas}

Variabel X dan Y

\begin{tabular}{|c|c|c|c|}
\hline $\begin{array}{c}\text { Variabel X } \\
\text { (Layanan Informasi Menggunakan Media } \\
\text { Film) }\end{array}$ & \multicolumn{2}{c|}{$\begin{array}{c}\text { Variabel Y } \\
\text { (Kepercayaan Diri ) }\end{array}$} \\
\hline No. Item & $\mathrm{r}_{\text {hitung }}$ & No. Item & $\mathrm{r}_{\text {hitung }}$ \\
\hline 1 & 0.892 & 1 & 0.659 \\
\hline 2 & 0.740 & 2 & 0.830 \\
\hline 3 & 0.699 & 3 & 0.777 \\
\hline 4 & 0.874 & 4 & 0.869 \\
\hline 5 & 0.894 & 5 & 0.889 \\
\hline 6 & 0.892 & 6 & 0.880 \\
\hline
\end{tabular}


Uji Normalitas dilakukan untuk mengetahui apakah distribusi data penelitian setiap variabel telah menyebar secara normal. Berikut ini tabel hasil perhitungan normalitas menggunakan rumus lilifors pada program SPSS version 17,0 For Windows.

Untuk hasil uji normalitas variabel x diperoleh signifikan $(\mathrm{p})(0.003)<(0.05)$, dan Variabel Y diperoleh signifikan $(\mathrm{p})(0.002)<(0.05)$ maka dari hasil data tersebut dapat disimpulkan bahwa data berdistribusi normal.

Uji homogenitas dilakukan untuk mengetahui apakah populasi dan sampel penelitian adalah homogen.Uji homogenitas dilakukan dengan menggunakan program SPSS for Windows versi 17.0. Berikut ini adalah tabel hasil uji homogenitas.

Berdasarkan perhitungan homogenitas untuk hasil uji homogenitas variabel $\mathrm{x}$ diperoleh signifikan (p) (0.604) > (0.05), dan Variabel Y diperoleh signifikan (p) (0.112) > (0.05) maka dari hasil data tersebut dapat disimpulkan bahwa sampel atau populasi yang bersifat homogen.

Untuk mengetahui pengaruh antara kedua variabel menggunakan analisis korelasi prusuct moment dengan bantuan program SPSS version 17.0 for windows. Berikut tabel hasil korelasi pengaruh layanan informasi menggunakan media film terhadap kepercayaan diri siswa.

Berdasarkan perhitungan diperoleh nilai koefesien korelasi sebesar 0.890 menyatakan bahwa terdapat Pengaruh Layanan Informasi Menggunakan Media Film Terhadap Kepercayaan Diri Siwa Kelas XI SMA Negeri 1 Binjai Tahun Pelajaran 2016/2017.

Selanjutnya untuk lebih jelasnya mengenai signifikan atau tidaknya kedua variabel maka menggunakan uji t sebagai berikut:

$$
\begin{aligned}
& t=\frac{r \sqrt{n-2}}{\sqrt{1-r^{2}}} \\
& =\frac{0.890 \sqrt{78-2}}{\sqrt{1-(0.890)^{2}}} \\
& =\frac{0.890 \sqrt{78}}{1-0.7921} \\
& =\frac{0.890(8,831)}{\sqrt{0.2079}} \\
& =\frac{7.859}{0.455} \\
& =17,27
\end{aligned}
$$


Berdasarkan perhitungan nalisis, hasil $\mathrm{t}_{\text {hitung }}=17,27$ dengan taraf signifikan nyata $\alpha=$ 0,05 dan dk yaitu $n=80-2=78$. Kemudian dapat dikatakan terdapat pengaruh yang signifikan antara kedua variabel jika $t_{\text {hitung }}>t_{\text {tabel }}$, dengan ketentuan nilai $t_{\text {tabel }}=1,98$, jadi dapat dilihat bahwa 17,27 > 1,98 sehingga dapat disimpulkan bahwa terdapat pengaruh layanan informasi menggunakan media film terhadap kepercayaan diri siswa kelas XI SMA Negeri 1 Binjai Tahun Pelajaran 2016/2017 dengan demikian hipotesis dinyatakan diterima.

\section{KESIMPULAN}

Berdasarkan seluruh perhitungan analisis penelitian ini diperoleh kesimpulan bahwa Pengaruh Layanan Informasi Menggunakan Media Film Terhadap Kepercayaan Diri Siswa Kelas XI SMA Negeri 1 Binjai Tahun Pelajaran 2016/2017. Terbukti melalui hasil uji hipotesis diperoleh data Variabel $\mathrm{X}$ dengan Mean $=16.80, \mathrm{SD}=4.300$ dengan $\mathrm{N}=80$ orang siswa dan Variabel $\mathrm{Y}$ dengan Mean=17.00, $\mathrm{SD}=4.314$ dengan $\mathrm{N}=80$ orang siswa. Dengan hasil penelitian perhitungan nalisis, hasil $\mathrm{t}_{\text {hitung }}=17,27$ dengan taraf signifikan nyata $\alpha=0,05$ dan dk yaitu $\mathrm{n}=80-2=78$. Kemudian dapat dikatakan terdapat pengaruh yang signifikan antara kedua variabel jika $t_{\text {hitung }}>t_{\text {tabel }}$, dengan ketentuan nilai $t_{\text {tabel }}=1,98$, jadi dapat dilihat bahwa 17,27 > 1,98 sehingga dapat disimpulkan bahwa terdapat pengaruh layanan informasi menggunakan media film terhadap kepercayaan diri siswa kelas XI SMA Negeri 1 Binjai Tahun Pelajaran 2016/2017 dengan demikian hipotesis dinyatakan diterima.

\section{REFERENSI}

Arikunto. Suharsismi. 2010. Prosedur penelitian suatu pendekatan praktik, Jakarta: Rineka Cipta, edisi revisi,

Aqib, Zainal. 2011. Bimbingan dan konseling di sekolah, Jakarta: Rajawali Press.

Arsyad, Azhar. 2003. Media pembelajaran, Jakarta: PT Raja Grafindo.

Barbara de.Engelis. 2014. Percaya diri sumber sukses dan kemandirian, Jakarta: PT Chandrawati.Nelly. go.id: Permendikbud No. 81 A Tahun 2013 tentang implementasi Kurikulum Lampiran IV Bagian VIII, di akses 20 Agustus 2014.

Gunawan. Yusuf. 2006. Pengantar bimbingan dan konseling dalam berbagai latarbelakang, Bandung: Refika Aditama,

Hakim. 2005. Mengatasi Rasa Tidak Percaya Diri, Jakarta: Puspa Swara.

Jogiyanto. HM. 1999. Analisis dan Disain Informasi: Pendekatan Terstruktur Teori dan Praktek Aplikasi Bisnis, Yogyakarta: Andi Offset. 
Luddin.Abu Bakar.M. 2010. Dasar-dasar Konseling Tinjauan Teori dan Praktik. Bandung: Cita Pusaka Media Perintis,

Nasution. 2011. Teknologi pendidikan, Jakarta: Bumi Aksara.

Nasution.Zulkarimein. 1984. Media dalam pembelajaran, Jakarta: CV.Rajawali.

Nurihsan Juntika A. 2006. Bimbingan dan konseling dalam berbagai latar belakang, Bandung: Refika Aditama.

Purwoko, Budi. 2008. Organisasi dan Managemen bimbingan dan konseling, Surabaya: Unesa University Press.

Prayitno dan Erman Amti. 2010. Dasar-dasar bimbingan dan konseling, Jakarta: Rieneka Cipta Edisi Revisi.

Slameto, 1986. Bimbingan di Sekolah, Salatiga: PT Bina Aksara.

Sukardi. Dewa Ketut, 2008. Pengantar Pelaksanaan Program Bimbingan dan Konseling di Sekolah, Jakarta: PT Rineka Cipta.

Sugiyono, 2010. Metode penelitian pendidikan, cet ke-11 Bandung: Alfabeta.

Sudjana, Nana. 1995. Dasar- dasar Proses Belajar Mengajar, Bandung: Sinar Baru Algesindo.

Suprijanto, 2009. Pendidikan orang dewasa, Jakarta: PT.Bumi Aksara.

Tohirin. 2009. Bimbingan dan konseling di sekolah dan madrasah berbasis integrasi, Jakarta: Rajawali Press.

Tim Pengembang. 2009. Ilmu dan Aplikasi Pendidikan, Bandung: PT IMTIMA.

Undang-Undang Republik Indonesia Nomor 20. 2004. Jakarta Pusat data dan informasi pendidikan Balitbang.

Usman, Basyiruddin. 2002. Media pembelajaran, Jakarta: Ciputat Pers.

Walgito, Bimo. 2005. Bimbingan dan konseling Studi \& Karir, Yogyakarta: Andi Offset.

Wardati dan Jauhar, 2011. Implementasi bimbingan \& konseling di sekolah,Jakarta: Prestasi Pustakaraya.

Winkel dan Sri Hastuti, 2006. Bimbingan dan Konseling di Institusi pendidikan. Yogyakarta: Media Abdi. 
